\title{
ANAK ANGKAT DALAM PERATURAN DI INDONESIA
}

\author{
Munadi Usman* \\ Institut Agama Islam Negeri (IAIN) Lhokseumawe
}

Email: munadiusman83@gmail.com

\begin{abstract}
The adoption of children in Indonesia is a long standing tradition with varied motives and goals depending on the customs of the people of a region or those who adopt children. Due to the large number of child adoptions, the government has issued several regulations relating to child adoption in the form of law, government regulation and Ministerial regulation. This study wants to examine the extent to which these regulations have accommodated the rights of adopted children in the family. This research is included in the study of normative law with the aim of analyzing the rules of adoption of children in Indonesia through a human rights approach or in Islam known as maqashid al-shariah.
\end{abstract}

Keywords: Adoption Child, Regulation, Indonesia

\begin{abstract}
Abstrak
Pengangkatan anak di Indonesia merupakan suatu tradisi yang telah berlangsung sejak lama dengan motif dan tujuan yang beragam tergantung adat kebiasaan masyarakat suatu daerah maupun individu yang mengangkat anak. Dengan maraknya pengangkatan anak, oleh pemerintah telah mengeluarkan sejumlah peraturan terkait pengangkatan anak baik berupa undang-undang, peraturan pemerintah maupun peraturan menteri. Penelitian ini ingin mengkaji sejauh mana peraturan-peraturan tersebut telah mengakomodir hak-hak anak angkat dalam keluarga. Penelitian ini tergolong ke dalam studi hukum normatif dengan tujuan menganalisis peraturan pengangkatan anak di Indonesia melalui pendekatan hak asasi manusia atau dalam Islam dikenal dengan maqashid al-syariah.
\end{abstract}

Kata Kunci: Anak Angkat, Peraturan, Indonesia

\section{Pendahuluan}

Praktek pengangkatan anak dalam masyarakat Indonesia telah melembaga dan telah menjadi suatu tradisi yang hidup. Sejak zaman dahulu masyarakat Indonesia telah melakukan adopsi dengan cara dan motivasi yang berbeda-beda, sesuai dengan sistem hukum adat yang berkembang di daerah masing-masing. Pengangkatan anak telah menjadi kebutuhan masyarakat yang semakin hari terus bertambah jumlahnya. ${ }^{1}$

Secara historis, pengaturan pengangkatan anak dalam peraturan perundang-undangan di Indonesia berjalan terseok-seok. Realita masyarakat yang majemuk (bhineka) dan adanya beberapa sistem hukum merupakan suatu

\section{Lhokseumawe.}

* Dosen Prodi Hukum Keluarga Islam, Institut Agama Islam Negeri (IAIN) 2004), hlm. 28.

${ }^{1}$ Soedaryo Soimin, Himpunan Dasar Hukum Pengangkatan Anak, (Jakarta: Sinar Grafika, 
ADHKI: Journal of Islamic Family Law

rintangan sekaligus tantangan dalam sistem pengembangan hukum di Indonesia, sehingga sulit untuk mendapatkan sistem hukum tunggal dan terpadu. ${ }^{2}$

Proses pengaturan pengangkatan anak dalam peraturan perundangundangan pada masyarakat Indonesia yang bhinneka (plural) tidak mudah dan mengalami banyak pertentangan. Sejak pasca proklamasi sampai awal era reformasi, hanya ada satu pasal yang mengatur pengangkatan anak, yaitu Pasal 12 Undang Undang Nomor 4 Tahun 1979 Tentang Kesejahteraan Anak. Dan ketentuan pasal itu pun sebatas tujuan pengangkatan anak. Sementara Staatsblad 1917 Nomor 129 warisan kolonial yang mengatur pengangkatan anak untuk penduduk golongan Tionghoa tersebut substansinya sudah ketinggalan zaman (out of date), bahkan secara perlahan dan pasti ditinggalkan oleh golongan Tionghoa sendiri.

Sejak melewati pintu gerbang proklamasi sampai memasuki pintu gerbang reformasi, tidak ada peraturan perundang-undangan yang mengatur secara memadai pelaksanaaan pengangkatan anak di Indonesia. Di era reformasi, pengaturan pengangkatan anak tersebut mulai terwujud dengan lahirnya Undang-Undang Nomor 23 Tahun 2002 tentang Perlindungan Anak, yang di dalamnya turut mengatur tentang pengangkatan anak. Kini, untuk melaksanakan ketentuan pengangkatan anak tersebut telah ditetapkan dan diundangkan pula Peraturan Pemerintah Nomor 54 Tahun 2007 tentang Pelaksanaan Pengangkatan Anak.

Tulisan ini ingin mengkompilasikan berbagai peraturan yang telah diterbitkan oleh pemerintah berkaitan dengan pengangkatan anak di Indonesia. Peraturan tersebut di uraikan secara sistematis berdasarkan hirarki perundangundangan dari yang paling tinggi sampai yang paling rendah, kemudian juga diurutkan berdasarkan tahun terbit. Di samping itu penulis juga melakukan analisis mendalam setiap peraturan tersebut menggunakan kaca mata cita hukum Islam dan hak asasi manusia, dengan tujuan dapat memahami sejauh mana peraturan tersebut telah mengakomodir hak-hak keperdataan anak angkat.

\section{Peraturan Pengangkatan Anak di Indonesia Hukum Adat}

Hukum adat mengatur seluruh aspek kehidupan masyarakat yang berasal dari nenek moyang dan berlaku secara turun-menurun. Hukum adat mengatur tentang masalah perkawinan, anak, warisan, tanah dan lain-lain yang selalu dipatuhi oleh setiap anggota masyarakat agar tercapai ketertiban dalam masyarakat. Hukum adat ini selalu dijunjung tinggi pelaksanaannya. Kedudukan hukum adat diakui secara konstitusional sebagai peraturan yang

${ }^{2}$ Musthofa Sy, Pengangkatan Anak Kewenangan Pengadilan Agama, Cet. 1, (Jakarta: Kencana Prenada Media Group, 2008), hlm. 20. 
berlaku sepanjang masih hidup dan sesuai dengan perkembangan masyarakat dan prinsip Negara Kesatuan Republik Indonesia. ${ }^{3}$

Menurut Ter haar dalam Bewa Ragawino, hukum adat adalah keseluruhan peraturan yang menjelma dalam keputusan-keputusan dari kepalakepala adat dan berlaku secara spontan dalam masyarakat. Artinya bahwa untuk melihat apakah sesuatu adat-istiadat itu sudah merupakan hukum adat, maka perlu melihat dari sikap penguasa masyarakat hukum terhadap sipelanggar peraturan adat-istiadat. Apabila penguasa menjatuhkan putusan hukuman terhadap sipelanggar maka adat-istiadat itu sudah merupakan hukum adat. ${ }^{4}$

Pengangkatan anak merupakan suatu institusi adat di Indonesia ada beragam prakteknya, setiap daerah memiliki tradisi dan ciri khas masing-masing mengenai pengangkatan anak. Berikut dikemukakan beberapa contoh praktek pengangkatan anak menurut hukum adat yang terdapat di beberapa daerah di Indonesia.

Di Jawa dan Sulawesi pengangkatan anak jarang dilakukan dengan sepengetahuan kepala desa. Mereka mengangkat anak dari kalangan keponakan. Pengangkatan anak dari keponakan ini lazimnya tanpa disertai pembayaran uang atau penyerahan barang kepada orang tua si anak. Di Bali, pengangkatan anak disebut "nyentanayang". Anak lazimnya diambil dari salah satu clan yang ada hubungan tradisionalnya, yaitu yang disebut purusa (pancer laki-laki). Tetapi akhir-akhir ini dapat pula diambil dari keluarga isteri (pradana).

Dalam masyarakat Nias, Lampung dan Kalimantan. Pertama-tama anak harus dilepaskan dari lingkungan lama serentak dengan pemberian imbalan, yaitu berupa benda magis, setelah penggantian dan penukaran itu berlangsung anak yang dipungut itu masuk ke dalam kerabat orang yang memungutnya, itulah yang disebut perbuatan ambil anak sebagai suatu perbuatan tunai. Pengangkatan anak itu dilaksanakan dengan suatu upacara dengan bantuan penghulu atau pemuka masyarakat secara terang dengan dihadiri masyarakat ramai. $^{5}$

Di Pontianak, syarat-syarat untuk dapat mengangkat anak adalah, disaksikan oleh pemuka adat, disetujui oleh kedua belah pihak, yaitu orang tua kandung dan orang tua angkat, anak telah meminum setetes darah dari orang tua angkatnya, membayar uang adat sebesar dua ulun (dinar) oleh si anak dan orang tuanya sebagai tanda pelepas atau pemisah anak tersebut, yakni bila pengangkatan anak tersebut dikehendaki oleh orangtua kandung anak tersebut. Sebaliknya bila pengangkatan anak tersebut dikehendaki oleh orang tua angkatnya maka ditiadakan pembayaran. Dan apabila dikehendaki oleh kedua

${ }^{3}$ Lihat Undang-undang Dasar 1945 Pasal 18 B ayat (2)

${ }^{4}$ Bewa Ragawino, Pengantar dan Asas-Asas Hukum Adat Indonesia, (Bandung: Fakultas Ilmu Sosial dan Ilmu Politik Unpad, tt), hlm. 12.

${ }^{5}$ Ter Haar, Asas-asas dan Susunan Hukum Adat, (Jakarta: Praditya Paramita), 1994, hlm. 182 
belah pihak maka masing-masing harus membayar adat sebesar dua $u l u n .{ }^{6}$

Dalam masyarakat Rejang di Provinsi Bengkulu lembaga pengangkatan anak yang dikenal dengan sebutan "Anak Aket" dengan cara calon orang tua angkat mengadakan selamatan yang dihadiri oleh ketua Kutai, pemuda dan masyarakat lainnya. Di dalam upacara itu ketua Kutai mengumumkan terjadinya pengangkatan anak yang kemudian disusul dengan upacara penyerahan anak yang akan diangkat oleh orang tua kandung dan penerimaan oleh orang tua angkat, maka secara adat resmilah pengangkatan anak tersebut.

Dalam adat Aceh, pengangkatan anak sudah lama dipraktekkan, anak angkat dalam adat Aceh dikenal dengan istilah "Aneuk Geutueng". Anak-anak ini biasanya adalah anak-anak saudara mereka yang kurang mampu, diambil untuk dipelihara dan diasuh. ${ }^{7}$

Selain yang telah dikemukakan di atas, masih banyak lagi praktek pengangkatan anak dalam kehidupan masyarakat adat di Indonesia yang tidak mungkin disebutkan seluruhnya di sini. Pengangkatan anak berdasarkan hukum adat disetiap daerah masih berlaku dan dianggap sah, serta melahirkan akibat hukum antara anak angkat dan orang tua angkatnya. Pengangkatan anak dalam hukum adat adalah perbuatan hukum dalam konteks hukum adat kekeluargaan. Bila anak telah diangkat sebagai anak orang lain, maka ia akan diposisikan secara sama dalam keluarga orang tua angkat baik secara fisik maupun sosial, padahal sebelumnya status tersebut tidak melekat padanya.

Seorang anak yang telah diangkat, melahirkan hak dan kewajiban terhadap orang tua angkat. Dalam sebahagian hukum waris adat anak angkat menjadi ahli waris layaknya anak kandung baik materiil maupun immaterial. Oleh karena itu pengangkatan anak dalam konteks hukum adat tidak hanya urusan orang tua, tetapi juga menjadi urusan kerabat dan anggota keluarga secara luas.

Prinsip hukum adat dalam suatu perbuatan adat harus terang dan tunai. ${ }^{8}$ Terang dalam arti suatu prinsip legalitas yang berarti perbuatan itu dilakukan dihadapan dan diumumkan dihadapan orang banyak, secara resmi dan formal dan mengupayakan semua orang mengetahuinya. Sedangkan tunai berarti perbuatan itu akan selesai seketika itu juga dan tidak mungkin ditarik kembali.

Begitu juga dalam hal pengangkatan anak, dalam hukum adat biasanya dilakukan dengan beberapa cara, tergantung pada tujuan dan akibat hukum dari perbuatan pengangkatan anak tersebut. ${ }^{9}$ Ada beberapa mekanisme pengangkatan anak dalam hukum adat, yaitu:

a. Pengangkatan anak secara terang dan tunai

${ }^{6}$ Amir Mertosedono, Tanya Jawab Pengangkatan Anak dan Masalahnya, (Semarang: Dahara Prize, 1987, hlm. 22.

${ }^{7}$ http://www.idlo.int/bandaacehawareness.HTM, di akses tanggal 31 Agustus 2014.

8 Bushar Muhammad, Pokok-Pokok Hukum Adat, (Jakarta: Pradya Paramita, 1981), hlm. 29.

${ }_{9}$ Afdhol, Pengangkatan Anak dan Aspek Hukumnya Dalam Hukum Adat, (Makalah dalam Seminar tentang "Pengaturan dan Akibat Hukum Pengangkatan Anak".) 
Secara terang berarti pengangkatan anak tersebut dilakukan dengan sepengetahuan dan dihadapan persekutuan (kepala adat) dengan melakukan upacara-upacara adat. Hal ini dilakukan untuk memberitahukan kepada khalayak bahwa ada upacara pemutusan hubungan hukum antara anak angkat dengan orang tua kandungnya, dan memasukkan anak angkat tersebut kedalam ikatan hak dan kewajiban orang tua angkat dan kerabat angkatnya.

Sedangkan yang dimaksud dengan tunai, bahwa perbuatan hukum pengangkatan anak harus disertai pemberian dan pembayaran adat berupa benda-benda magis, uang, emas dan pakaian. Dengan adanya pemberianpemberian tersebut, maka pengangkatan anak telah selesai dilakukan. Dan ketika itu juga anak angkat beralih hubungan dari orang tua kandungnya kepada orang tua angkat. Dengan selesainya pengangkatan anak, maka tidak mungkin dibatalkan atau ditarik kembali.

Pada masyarakat adat yang menganut pengangkatan anak sebagai perbuatan hukum untuk menjadikan anak orang lain sebagai anak kandung orang tua angkat, anak angkat selain dimasukkan dalam ikatan rumah tangga orang tua angkat, secara sosial ia juga dimasukkan kedalam ikatan kekerabatan orang tua angkat. Anak angkat dalam masyarakat adat seperti ini menduduki posisi sebagai ahli waris dari orang tua angkat, baik terhadap harta benda yang bersifat materiil maupun immaterial (gelar-gelar kebangsawanan). Oleh karenanya pengangkatan anak dalam masyarakat seperti ini harus secara terang dan tunai.

b. Pengangkatan anak tidak secara terang dan tunai.

Pada pengangkatan anak yang tidak bertujuan untuk menjadikan anak angkat sebagai anak kandung, maka tidak perlu dilakukan secara terang dan tunai. Di Jawa, pada umumnya pengangkatan anak tidak memutuskan hubungan darah anak angkat dengan orang tua kandungnya. Namun pengangkatan anak hanya bertujuan untuk memasukkan anak tersebut ke dalam keluarga orang tua angkat saja untuk diasuh. Anak tersebut tidak berfungsi untuk meneruskan keturunan orang tua angkat, kebanyakan anak yang diangkat dalam hal ini adalah keponakannya sendiri.

Pada masyarakat Jawa dan Sulawesi, perbuatan hukum pengangkatan anak tidak dilakukan secara terang dan tunai, karena mereka menganggap hal itu tidak mesti dilakukan di hadapan dan sepengetahuan kepala adat untuk keabsahannya. Dan juga tidak harus melakukan penyerahan atau pemberian sesuatu untuk orang tua kandung anak tersebut. Sedangkan dari orang tua angkat ia berhak mendapatkan harta gono-gini sebagai anggota dari keluarga orang tua angkat.

Berdasarkan penjelasan di atas dapat dipahami bahwa pengangkatan anak dalam hukum adat terbagi kepada dua, yaitu; Pertama, pengangkatan anak yang memutuskan tali ikatan kekerabatan dengan orang tua kandung, maka hubungan segala hubungan keperdataan anak angkat berpindah kepada orang tua angkat, baik materil maupun immateriil. Pengangkatan macam ini biasanya dilakukan secara tunai dan terang. 
Kedua, pengangkatan anak yang tidak memutuskan tali kekerabatan anak angkat dengan orang tua kandung. Pengangkatan anak macam ini hanya sebatas untuk memasukkan anak angkat dalam keluarga orang tua angkat untuk kepentingan pengasuhan dan pembiayaan hidup. Sedangkan hubungannya dengan orang tua kandung masih tersambung. Praktek pengangkatan anak seperti ini banyak ditemukan di daerah yang mayoritas muslim seperti Jawa dan Sulawesi. Pengangkatan macam ini biasanya dilakukan secara diam-diam tanpa melibatkan petua adat, dan tidak memberitahukan kepada masyarakat ramai.

\section{Kitab Undang-Undang Hukum Perdata Barat (Burgerlijk Wetboek)}

Dalam Kitab Undang-Undang Hukum Perdata Barat (Burgerlijk Wetbook) tidak ditemukan satu ketentuan yang mengatur masalah adopsi atau anak angkat. Burgerlijk Wetboek hanya mengatur tentang ketentuan pengakuan anak luar kawin. Sedangkan lembaga anak luar kawin dan anak angkat tidak sama. Mengingat kebutuhan masyarakat tentang pengangkatan anak telah meningkat, di samping kultur budaya Indonesia asli dan masyarakat Tionghoa telah lama mempraktikkan pengangkatan anak, maka Pemerintah Hindia Belanda mengeluarkan Staadsblad 1917 Nomor 129 yang isinya mengatur secara khusus tentang lembaga pengangkatan anak untuk melengkapi Burgerlijk Wetboek $(\mathrm{BW}) \cdot{ }^{10}$

Adanya penggolongan penduduk pada masa pemerintahan HindiaBelanda berakibat pada berlakunya beragam hukum bagi masing-masing golongan. Berdasarkan Staatsblad 1847 Nomor 23, hukum perdata yang berlaku bagi kalangan Eropa adalah hukum perdata Belanda (Burgerlijk Wetboek). Golongan Timur Asing (Arab, India dan Pakistan) berlaku sebahagian dari Burgerlijk Wetboek, dan selebihnya yang menyangkut hukum perseorangan, hukum keluarga dan hukum waris berlaku hukum mereka sendiri, yaitu hukum Islam sebagaimana Staatsblad 1924 Nomor 556. Sedangkan untuk golongan Bumi Putera yang beragama Kristen, berdasarkan Pasal 131 ayat (4) Indische Staatssregeling berlaku hukum adat. ${ }^{11}$

Berdasarkan Staatsblad 1917 Nomor 129 kemudian ditambah Staatsblad 1924 Nomor 556, bahwa hampir seluruh Kitab Undang Undang Hukum Perdata (Burgerlijk Wetboek) dinyatakan berlaku bagi golongan Tionghoa, dengan beberapa pengecualian dan ada pula lembaga yang diberikan pengaturan secara khusus, yaitu perihal pengangkatan anak.

Staatsblad 1917 Nomor 129 adalah peraturan pengangkatan yang anak diatur secara khusus berdasarkan adat, pandangan dan kepercayaan warga

10 Ahmad Kamil dan Fauzan, Hukum Perlindungan dan Pengangkatan Anak di Indonesia, (Jakarta: Raja Grafindo, 2008), hlm. 20.

${ }^{11}$ Musthofa Sy, Pengangkatan Anak Kewenangan Pengadilan Agama..., hlm. 24-25. 
Tionghoa dan hanya berlaku untuk mereka. ${ }^{12}$ Sedangkan Kitab Undang Undang Hukum Perdata (Burgerlijk Wetboek) memandang perkawinan sebagai bentuk hidup bersama bukan untuk mengadakan keturunan, sehingga tidak mengenal lembaga pengangkatan anak. ${ }^{13}$

Namun dalam perkembangannya sejak Tahun 1956 Burgerlijk Wetboek Belanda yang baru (Nieuwe Burgerlijk Wetboek) telah mengatur pengangkatan anak, pengaturan ini dilatarbelakangi oleh keinginan sebahagian masyarakat untuk memelihara anak-anak yang kehilangan orang tua akibat peristiwa perang dunia ke II yang banyak menimbulkan korban jiwa.

Ketentuan tentang pengangkatan anak dalam Staatsblad 1917 Nomor 129 antara lain diatur dalam Pasal 5 ayat (1), (2) dan (3) yang berbunyi:

(1) Seorang yang telah beristeri atau pernah beristeri dan tidak mempunyai keturunan laki-laki yang sah dalam garis keturunan laki-laki, baik keturunan karena kelahiran atau keturunan kerena pengangkatan anak, maka bolehlah ia mengangkat anak laki-laki sebagai anaknya.

(2) Orang laki-laki bersama istrinya atau oleh suami itu sendiri, jika pengangkatan itu dilakukan sebelum perkawinannya bubar.

(3) Janda yang tidak menikah lagi, dengan syarat bahwa almarhum suaminya tidak meninggalkan keturunan laki-laki dan tidak meninggalkan wasiat yang melarang melakukan pengangkatan anak oleh jandanya.

Pada Pasal 5 ayat (1) di atas menegaskan bahwa pengangkatan anak hanya dapat dilakukan oleh orang yang telah beristeri atau pernah memiliki isteri yang tidak mempunyai keturunan secara kelahiran maupun pengangkatan. Dan anak yang diangkat harus laki-laki. Ayat (1) ini menjelaskan tentang kriteria orang tua angkat dan anak angkat. Orang tua angkat disyaratkan telah pernah kawin dan belum memiliki keturunan dengan perkawinan atau pengangkatan. Maka pengangkatan anak oleh orang yang belum kawin tidak dibenarkan. Selanjutnya anak yang diangkat harus laki-laki, sedangkan perempuan tidak dibolehkan.

Pada ayat (2) disebutkan bahwa pengangkatan anak tersebut harus dilakukan oleh orang laki-laki bersama isterinya atau jika kedua telah bercerai, maka oleh laki-laki itu sendiri. Sedangkan pada ayat (3) disebutkan untuk janda yang tidak kawin lagi, dan oleh suaminya yang telah meninggal dunia tidak meninggalkan keturunan sebagaimana termasuk pada ayat (1), dan tidak meninggalkan surat wasiat bahwa suami tidak menghendaki pengangkatan anak oleh isterinya, boleh mengangkat seorang anak laki-laki sebagai anaknya. Sebaliknya jika suami telah meninggal dan meninggalkan surat wasiat yang tidak menghendaki pengangkatan anak oleh isterinya, maka janda tersebut tidak boleh melakukan pengangkatan anak.

${ }^{12}$ J. Satrio, Hukum Keluarga Tentang Kedudukan Anak Dalam Undang-Undang, (Bandung: Citra Aditya Bakti, 2000), hlm. 190-193.

${ }^{13}$ Ali Affandi, Hukum Waris Keluarga Hukum Pembuktian Menurut Kitab Undang Undang Hukum Perdata (BW), (Jakarta: Bina Aksara, 1986), hlm. 149. 
ADHKI: Journal of Islamic Family Law

Ketentuan tentang anak yang dapat diadopsi diatur pada pasal 6 dan pasal 7 ayat 1 dan 2, bunyi kedua pasal tersebut adalah:

Pasal 6;

"Anak yang boleh diangkat adalah anak laki-laki Tionghoa yang belum beristeri dan beranak, serta belum pernah diangkat oleh orang lain."

Pasal 7;

(1) Anak yang diangkat minimal harus 18 tahun lebih muda dari suami dan minimal 15 tahun lebih muda dari isteri atau janda yang mengangkatnya."

(2) Dapat diambil dari luar keluarga atau dari dalam keluarga, baik yang sah maupun luar kawin.

Berdasarkan ketentuan Pasal 6 dan 7 di atas bahwa anak yang dapat diangkat hanyalah laki-laki keturunan Tionghoa yang belum kawin dan belum pernah diambil sebagai anak orang lain. Ketentuan dari Staatsblad 1917 Nomor 129 berangkat dari suatu sistem kepercayaan dalam budaya Tionghoa, bahwa anak laki-laki meneruskan keturunan, di samping itu yang lebih penting bahwa anak laki-lakilah yang dapat memelihara abu leluhur orang tuanya. Karena itu mereka enggan anak laki-laki mereka diangkat oleh orang lain, kecuali keluarga tersebut tidak sanggup memberi nafkah untuk kebutuhan anak-anaknya. Namun dalam perkembangan dikemudiannya anak perempuan juga dapat diangkat. ${ }^{14}$

Ketentuan-ketentuan dalam Staatsblad 1917 Nomor 129 mengalami perubahan dan perkembangan yang terjadi sejak tahun 1963, antara lain dengan munculnya putusan Pengadilan Negeri seperti yang dikemukakan dalam media "PROJUSTITIA", di antaranya:

a. Pada Tahun 1963 telah terjadi pengangkatan anak perempuan melalui putusan Pengadilan Negeri Istimewa Jakarta tanggal 29 Mei 1963, Nomor 907/1963.

b. Keputusan Pengadilan Negeri Jakarta tanggal 17 Oktober 1963, Nomor 588/1963 G, yang sering disebut dengan Yurisprudensi pengangkatan anak perempuan.

c. Ketetapan Pengadilan Negeri Bandung dalam penetapannya tanggal 26 Februari 1970 Nomor 32/1970 mengenai pengangkatan anak perempuan oleh seorang perempuan yang telah menikah. Pengadilan Negeri Bandung dalam penetapannya tersebut memberikan pertimbangan adalah; "Menurut hemat kami yang harus dipertimbangkan lebih dari segalanya adalah kepentingan dari si anak dan seterusnya"

Putusan-putusan tersebut didasarkan atas pertimbangan lembaga pengangkatan anak semata-mata untuk menyambung keturunan, akan tetapi lebih dari itu dimaksudkan untuk kepentingan anak. Oleh karenanya untuk kebutuhan pengangkatan anak tidak mesti anak laki-laki, namun juga anak

14 Putusan Pengadilan Negeri Istimewa Jakarta, dalam Putusan Tanggal 29 Mei 1963, Nomor 907/1963 
perempuan jika dianggap anak tersebut membutuhkan untuk diangkat menjadi anak orang lain.

\section{Undang-Undang Nomor 4 Tahun 1979 tentang Kesejahteraan Anak}

Anak adalah potensi generasi penerus cita-cita bangsa dan anak-anak diharapkan mampu memikulnya. Untuk itu kesejahteraan mereka juga harus dipenuhi dengan baik. Atas dasar itu maka dibentuklah Undang-Undang Nomor 4 Tahun 1979 tentang Kesejahteraan Anak. Dalam undang-undang ini tentang pengangkatan anak diatur pada pasal 12 ayat 1, 2 dan 3. Adapun bunyi pasal tersebut adalah:

(1) Pengangkatan anak menurut adat dan kebiasaan dilaksanakan dengan mengutamakan kepentingan kesejahteraan anak.

(2) Kepentingan kesejahteraan anak yang termaksud dalam ayat (1) diatur lebih lanjut dengan Peraturan Pemerintah.

(3) Pengangkatan anak untuk kepentingan kesejahteraan anak yang dilakukan di luar adat dan kebiasaan, dilaksanakan berdasarkan Peraturan Perundang-undangan. ${ }^{15}$

Berdasarkan pasal 12 di atas dapat dipahami bahwa pengangkatan anak menurut Undang Undang Kesejahteraan Anak harus dilakukan berdasarkan hukum adat sebagaimana ditegaskan pada ayat 1. Jika tidak dilakukan berdasarkan hukum adat, maka harus mengacu kepada aturan perundangundangan, sebagaimana ditegaskan pada ayat 3. Adapun tujuan dari pengangkatan anak tidak lain adalah untuk kepentingan kesejahteraan anak.

Ketentuan mengenai pengangkatan anak dalam Undang-Undang Nomor 4 Tahun 1979 Tentang Kesejahteraan Anak masih sangat umum, yaitu hanya mengatur tentang dasar hukum dan tujuan dari pengangkatan anak saja. Sedangkan subtansi hukum dan akibat hukum dari pengangkatan anak sama sekali tidak disentuh, hal ini sepenuhnya diserahkan kepada ketentuan adat dan perundang-undangan yang berlaku. Adapun perundang-undangan yang mengatur tentang pengangkatan anak ketika itu adalah Staatsblad 1917 Nomor 129.

\section{Undang-undang Nomor 23 Tahun 2002 tentang Perlindungan Anak}

Kondisi ekonomi nasional yang kurang baik, turut mempengaruhi kesejahteraan ekonomi keluarga dan berdampak kepada tingkat kesejahteraan anak Indonesia. Kenyataan yang lumrah dijumpai bahwa banyak anak yang hidup belum menguntungkan, di mana ditemukan anak-anak jalanan, anak terlantar, yatim piatu dan penyandang cacat yang perlu penangganan, pembinaan dan perlindungan, baik dari pihak pemerintah maupun masyarakat.

Untuk itu pemerintah telah membuat Undang-Undang Nomor 23 Tahun 2002 tentang Perlindungan Anak. Undang-undang ini mengatur tentang upaya-

${ }_{15}$ Undang Undang Republik Indonesia Nomor 4 Tahun 1979, Tentang Kesejahteraan Anak, LN Nomor 32 Tahun 1979. 
upaya yang dilakukan dalam rangka perlindungan, pemenuhan hak-hak dan peningkatan kesejahteraan anak. Salah satu solusi penangganan masalah anak tersebut adalah memberikan kesempatan kepada orang tua yang mampu untuk mengangkatnya. Dan pengangkatan anak ini semata-mata untuk kepentingan kesejahteraan anak berdasarkan peraturan perundang-undangan dan adat kebiasaan setempat.

Dalam Undang Undang Nomor 23 Tahun 2002 Tentang Perlindungan Anak juga diatur tentang pengangkatan anak, antara lain termuat pada Pasal 1 ayat 9 yang berbunyi: "Anak angkat adalah anak yang haknya dialihkan dari lingkungan kekuasaan keluarga orang tua, wali yang sah, atau orang lain yang bertanggung jawab atas perawatan, pendidikan, dan membesarkan anak tersebut, ke dalam lingkungan keluarga orang tua angkatnya berdasarkan putusan atau penetapan pengadilan."16

Dari pengertian di atas, dapat dipahami bahwa anak angkat adalah anak yang telah dialihkan tanggungjawab perawatan, pendidikan dan membesarkannya dari keluarga orang tua, wali sah dan orang lain kepada orang tua angkat. Adapun tujuan pengangkatan anak adalah semata-mata untuk peralihan tanggungjawab pemenuhan kebutuhan anak dari orang tuanya kepada orang tua angkat, supaya anak dapat tumbuh sehat dan memiliki pendidikan yang memadai.

Orang tua angkat harus memberitahukan asal usul anak angkat pada waktu yang tepat, sebagaimana diatur pada Pasal 7 ayat (1) dan (2) yang berbunyi:

(1) Setiap anak berhak untuk mengetahui orang tuanya, dibesarkan, dan diasuh oleh orang tuanya sendiri.

(2) Dalam hal karena suatu sebab orang tuanya tidak dapat menjamin tumbuh kembang anak, atau anak dalam keadaan terlantar maka anak tersebut berhak diasuh atau diangkat sebagai anak asuh atau anak angkat oleh orang lain sesuai dengan ketentuan peraturan perundang-undangan yang berlaku. ${ }^{17}$

Pasal di atas menegaskan bahwa anak angkat berhak untuk mengetahui siapa orang tuanya, dibesarkan dan diasuh oleh orang tuanya sendiri. Hak asuh orang tua tidak dapat dialihkan kepada orang lain masih sanggup dilakukan sendiri. Namun jika orang tua tidak sanggup mengasuhnya, atau anak tersebut sama sekali tidak memiliki orang tua dan wali, maka hak asuhnya dapat dialihkan kepada orang lain, dengan menjadikan sebagai anak asuh atau anak angkat.

Ketentuan pada Pasal 7 ayat 1 dan 2 di atas juga sesuai dengan isi Pasal 14 yang berbunyi: "Setiap anak berhak untuk diasuh oleh orang tuanya sendiri, kecuali

\footnotetext{
${ }^{16}$ Undang Undang Republik Indonesia Nomor 23 Tahun 2002, Tentang Perlindungan Anak, LN Nomor 109 Tahun 2002.

17 Undang Undang Republik Indonesia Nomor 23 Tahun 2002, Tentang Perlindungan Anak, LN Nomor 109 Tahun 2002.
} 
jika ada alasan dan/atau aturan hukum yang sah menunjukkan bahwa pemisahan itu adalah demi kepentingan terbaik bagi anak dan merupakan pertimbangan terakhir."

Setiap anak tidak dapat dipisahkan dari orang tuanya untuk hidup bersama dan menerima asuhan orang tuanya. Memisahkan anak dengan orang tuanya merupakan pelanggaran terhadap hak anak, kecuali dengan alasan tertentu demi kebaikan si anak, maka memisahkan anak dari orang tuanya dibolehkan. Misalnya orang tua yang sering mengabaikan hak asuh anakanaknya, melakukan kekerasan yang membahayakan keselamatan anak, menjerumuskan anak kepada hal yang negatif seperti prostitusi, kriminal dan lainnya. Dengan demikian, hak asuh anak dapat dicabut dan anak tersebut dialih kepada orang lain atau lembaga pengasuhan anak.

Orang tua memiliki kewajiban mengasuh anaknya dan menumbuhkembangkan sesuai bakat, minat dan kemampuan anak serta menjaga anak agar terhindar dari segala yang membahayakan hidupnya, sebagaimana diatur pada Pasal 26 ayat 1 dan 2 yang berbunyi:

(1) Orang tua berkewajiban dan bertanggung jawab untuk:

- mengasuh, memelihara, mendidik, dan melindungi anak;

- menumbuhkembangkan anak sesuai dengan kemampuan, bakat, dan minatnya; dan

- mencegah terjadinya perkawinan pada usia anak-anak.

(2) Dalam hal orang tua tidak ada, atau tidak diketahui keberadaannya, atau karena suatu sebab, tidak dapat melaksanakan kewajiban dan tanggung jawabnya, maka kewajiban dan tanggung jawab sebagaimana dimaksud dalam ayat (1) dapat beralih kepada keluarga, yang dilaksanakan sesuai dengan ketentuan peraturan perundang-undangan yang berlaku..$^{18}$

Orang tua yang mengabaikan tanggungjawab terhadap anak, atau bahkan kadang melakukan tindakan-tindakan yang membahayakan anak maka hak asuhnya dapat dicabut, sebagaimana ditegaskan pada Pasal 30 yang berbunyi: "Dalam hal orang tua sebagaimana dimaksud dalam Pasal 26, melalaikan kewajibannya, terhadapnya dapat dilakukan tindakan pengawasan atau kuasa asuh orang tua dapat dicabut."

Negara sangat memperhatikan hak-hak anak supaya terpenuhi dan mengawasi pertumbuhan anak supaya dapat tumbuh normal dan menghindari segala tindakan yang membahayakan bagi kehidupan anak, oleh sebab itu jika orang tua tidak menjalankan tugas pengasuhan sebagaimana mestinya, maka negara berhak mencabut hak asuh.

Jika hak asuh orang tua telah dicabut, maka pemerintah melalui pengadilan dapat menunjuk perseorangan atau lembaga pemerintah atau masyarakat untuk menjadi wali bagi anak. Mengenai ketentuan pencabutan hak

${ }_{18}$ Undang Undang Republik Indonesia Nomor 23 Tahun 2002, Tentang Perlindungan Anak, LN Nomor 109 Tahun 2002. 
ADHKI: Journal of Islamic Family Law

asuh, penetapan pengadilan dan agama orang tua asuh diatur pada Pasal 31 ayat 2, 3 dan 4 yang berbunyi:

(2) Apabila salah satu orang tua, saudara kandung, atau keluarga sampai dengan derajat ketiga, tidak dapat melaksanakan fungsinya, maka pencabutan kuasa asuh orang tua sebagaimana dimaksud dalam ayat (1) dapat juga diajukan oleh pejabat yang berwenang atau lembaga lain yang mempunyai kewenangan untuk itu.

(3) Penetapan pengadilan sebagaimana dimaksud dalam ayat (1) dapat menunjuk orang perseorangan atau lembaga pemerintah/masyarakat untuk menjadi wali bagi yang bersangkutan.

(4) Perseorangan yang melaksanakan pengasuhan anak sebagaimana dimaksud dalam ayat (3) harus seagama dengan agama yang dianut anak yang akan diasuhnya. ${ }^{19}$

Selanjutnya pada Pasal 32 diatur beberapa ketentuan lainnya menyangkut pengasuhan anak, yang menyangkut hubungan darah, kewajiban orang tua dan batas waktu pencabutan hak asuh, yaitu: Penetapan pengadilan sebagaimana dimaksud dalam Pasal 31 ayat (3) sekurang-kurangnya memuat ketentuan:

- tidak memutuskan hubungan darah antara anak dan orang tua kandungnya;

- tidak menghilangkan kewajiban orang tuanya untuk membiayai hidup anaknya; dan

- $\quad$ batas waktu pencabutan..$^{20}$

Dengan demikian dapat dipahami bahwa pengangkatan anak menurut Undang-Undang Nomor 23 Tahun 2002 Tentang Perlindungan Anak merupakan upaya terakhir jika orang tua anak atau wali anak tersebut tidak dapat menjalankan fungsi pengasuhan sebagaimana mestinya. Pemerintah dapat mencabut hak asuh orang tua dan menunjukkan orang lain atau lembaga untuk mengasuh anak tersebut.

Namun dalam pengasuhan/pengangkatan anak ini harus diperhatikan beberapa hal. Pertama, harus dipastikan bahwa agama orang tua asuh dan anak asuh harus sama, guna menghindari tindakan pemaksaan agama orang tua asuh terhadap anak asuh oleh dikemudian hari. Kedua, hak asuh tidak memutuskan hubungan darah antara anak dengan orang tua kandungnya. Namun anak tersebut tetap merupakan penerus keturunan dan ahli waris dari orang tuanya.

\section{Undang-Undang Republik Indonesia Nomor 12 Tahun 2006 tentang Perubahan Atas Undang-Undang Nomor 62 Tahun 1958 tentang Kewarganegaraan Republik Indonesia}

Undang-Undang Nomor 12 Tahun 2006 mengatur tentang kewarganegaraan bagi warga negara Indonesia dan merupakan perubahan atas undang-undang kewarganegaraan sebelumnya yaitu Undang-undang Nomor 62

\footnotetext{
${ }^{19}$ Undang Undang Republik Indonesia Nomor 23 Tahun 2002, Tentang Perlindungan Anak, LN Nomor 109 Tahun 2002.

${ }^{20}$ Undang Undang Republik Indonesia Nomor 23 Tahun 2002, Tentang Perlindungan Anak, LN Nomor 109 Tahun 2002.
} 
tahun 1958. Dalam Undang-undang Nomor 12 Tahun 2006 tentang warga negara Indonesia diatur antara lain pada pasal 2 yang berbunyi: "Yang menjadi Warga Negara Indonesia adalah orang-orang bangsa Indonesia asli dan orang-orang bangsa lain yang disahkan dengan undang-undang sebagai warga negara." 21

Dari pasal 2 di atas dapat dipahami bahwa warga negara Indonesia terdiri dari orang-orang bangsa Indonesia asli dan orang asing yang telah disahkan undang-undang menjadi warga negara Indonesia. Pasal ini memungkinkan warga negara lain menjadi warga negara Indonesia melalui pewarganegaraan termasuk anak asing yang diangkat oleh warga negara Indonesia berhak memperoleh kewarganegaraan Indonesia jika telah dilakukan permohonan dan telah disahkan.

Mengenai anak angkat dalam Undang-Undang ini diatur pada Pasal 5 ayat 2 yang berbunyi: "Anak Warga Negara Indonesia yang belum berusia 5 (lima) tahun diangkat secara sah sebagai anak oleh warga negara asing berdasarkan penetapan pengadilan tetap diakui sebagai Warga Negara Indonesia."22

Pasal di atas menunjukkan kebolehan pengangkatan anak baik oleh warga negara Indonesia maupun oleh warga negara asing. Anak warga Negara Indonesia yang belum berusia lima tahun yang diangkat secara sah sebagai anak oleh warga negara asing tetap diakui sebagai Warga Negara Indonesia. Demikian pula sebaliknya anak warga negara asing belum berusia 5 tahun yang diangkat oleh warga Negara Indonesia berhak memperoleh kewarganegaraan Republik Indonesia. Hal ini sebagaimana diatur pada pasal 21 ayat 2 yang berbunyi: "Anak warga negara asing yang belum berusia 5 (lima) tahun yang diangkat secara sah menurut penetapan pengadilan sebagai anak oleh Warga Negara Indonesia memperoleh Kewarganegaraan Republik Indonesia."

Berdasarkan ketentuan pasal 5 dan 21 memungkinkan anak memperoleh kewarganegaraan ganda dari Negara Indonesia dan negara asing. Maka anak akan diberikan kebebasan untuk memilih kewarganegaraan ketika usianya memasuki 18 tahun atau sudah kawin, sebagaimana diatur dalam pasal 6 ayat 1 , 2 dan 3 yang berbunyi:

(1) Dalam hal status Kewarganegaraan Republik Indonesia terhadap anak sebagaimana dimaksud dalam Pasal 4 huruf $c$, huruf $d$, huruf h, huruf $l$, dan Pasal 5 berakibat anak berkewarganegaraan ganda, setelah berusia 18 (delapan belas) tahun atau sudah kawin anak tersebut harus menyatakan memilih salah satu kewarganegaraannya.

(2) Pernyataan untuk memilih kewarganegaraan sebagaimana dimaksud pada ayat (1) dibuat secara tertulis dan disampaikan kepada Pejabat dengan melampirkan dokumen sebagaimana ditentukan di dalam peraturan perundang-undangan.

\footnotetext{
${ }^{21}$ Undang-Undang Nomor 12 Tahun 2006, Tentang Kewarganegaraan Republik Indonesia, LN Nomor 63 Tahun 2006.

${ }^{22}$ Undang-Undang Nomor 12 Tahun 2006, Tentang Kewarganegaraan Republik Indonesia, LN Nomor 63 Tahun 2006.
} 
ADHKI: Journal of Islamic Family Law

(3) Pernyataan untuk memilih kewarganegaraan sebagaimana dimaksud pada ayat (2) disampaikan dalam waktu paling lambat 3 (tiga) tahun setelah anak berusia 18 (delapan belas) tahun atau sudah kawin.

\section{Undang-Undang Nomor 3 Tahun 2006 tentang Perubahan atas Undang- Undang Nomor 7 Tahun 1989 tentang Pengadilan Agama;}

Untuk umat Islam pengangkatan anak harus mengacu kepada Undang Undang Nomor 3 Tahun 2006 tentang Perubahan atas Undang-Undang Nomor 7 tahun 1989 tentang Pengadilan Agama. Penetapan Pengangkatan Anak berdasarkan Hukum Islam antar orang-orang yang beragama Islam di Indonesia telah menjadi wewenang Pengadilan Agama sejak lahirnya undang-undang ini, sebagaimana termuat pada angka 20 huruf (a) penjelasan pasal 49 undangundang tersebut.

Munculnya undang-undang ini membawa pengaruh yang signifikan pada sistem pengangkatan anak di Indonesia. Setidaknya muncul dualisme pemahaman menyangkut kewenangan pengangkatan anak bagi warga yang beragama Islam. Dalam prakteknya tentu akan dijumpai orang-orang Islam yang melakukan adopsi di hadapan Pengadilan Negeri dengan segala konsekwensinya. Yang jelas berdasarkan Undang Undang Nomor 3 Tahun 2006 tersebut masyarakat Islam telah diberikan wadah dan payung hukum dalam memformalisasikan pengangkatan anak melalui Pengadilan Agama dan hukum terapannya adalah Kompilasi Hukum Islam serta doktrin hukum Islam yang terdapat dalam kitab-kitab fiqih baik klasik maupun kontemporer.

Kompilasi Hukum Islam (KHI) sebagai fikih ala Indonesia pada Pasal 171 huruf $\mathrm{h}$ mengatur tentang anak angkat menurut hukum Islam. Pasal tersebut berbunyi: "Anak angkat adalah anak yang dalam pemeliharaan hidupnya sehari-hari, biaya pendidikan dan sebagainya beralih tanggung jawab dari orang tua asal kepada orang tua angkatnya berdasarkan putusan Pengadilan". ${ }^{23}$

Atas dasar azas personalitas keislaman maka pengadilan yang dimaksud dalam pasal tersebut adalah jika orang tua angkat maupun anak yang diangkat adalah orang-orang Islam adalah Pengadilan Agama. Dengan demikian pelaksanaan pengangkatan anak akan dilakukan berdasarkan hukum Islam.

Hukum Islam selalu elastis dan berkembang, namun ada ketentuan yang tetap, oleh karena itu ada beberapa hal yang harus diperhatikan dalam penetapan anak angkat di hadapan Pengadilan Agama, yaitu:

1) Anak angkat tidak dapat menggunakan nama ayah angkatnya, seperti dijelaskan oleh ayat 5 surat Al-Ahzab;

2) Antara anak angkat dengan ayah angkat, ibu angkat dan saudara angkat tidak mempunyai hubungan darah. Mereka dapat tinggal serumah, tetapi harus menjaga ketentuan mahram dalam hukum Islam, antara lain

23 Departemen Agama RI, Tanya Jawab Kompilasi Hukum Islam, (Direktorat Jenderal Pembinaan Kelembagaan Agama Islam, 1997/1998), hlm. 134. 
ketentuan-ketentuan berkaitan dengan aurat, berkhalwat, masalah wali nikah untuk anak perempuan dan lain-lain.

3) Diantara mereka tidak saling mewarisi. Dengan demikian Pengangkatan anak berdasarkan hukum Islam seperti yang disebut oleh Undang Undang Nomor 3 Tahun 2006 Tentang Perubahan Atas Undang Undang Nomor 7 Tahun 1989 Tentang Pengadilan Agama tidak boleh bertentangan dengan kasus Zaid bin Haritsah.

\section{Undang Undang Nomor 24 Tahun 2013 tentang Perubahan Atas Undang-Undang Nomor 23 Tahun 2006 tentang Administrasi Kependudukan.}

Menurut Undang Undang Nomor 23 Tahun 2013 Tentang Administrasi Kependudukan bahwa setiap peristiwa penting yang di alami oleh penduduk harus dicatat, sebagaimana ketetapan nomor 15 undang-undang ini yang berbunyi: Pencatatan Sipil adalah pencatatan Peristiwa Penting yang dialami oleh seseorang dalam register Pencatatan Sipil pada Instansi Pelaksana. ${ }^{24}$

Sedangkan pada ketetapan nomor berikutnya yaitu nomor 16 dirincikan beberapa peristiwa penting tersebut antara lain adalah pengangkatan anak. bunyi ketetapan tersebut adalah: Peristiwa Penting adalah kejadian yang dialami oleh seseorang meliputi kelahiran, kematian, lahir mati, perkawinan, perceraian, pengakuan anak, pengesahan anak, pengangkatan anak, perubahan nama dan perubahan status kewarganegaraan..$^{25}$

Dengan demikian dapat dipahami bahwa pengangkatan anak adalah salah satu peristiwa penting yang turut diperhatikan oleh prundang-undangan di Indonesia, peristiwa tersebut harus dilaporkan kepada pihak yang berwenang untuk dicatat selanjutnya dikeluarkan suatu dokumen resmi yang berisi tentang pengangkatan anak.

\section{Peraturan Pemerintah Republik Indonesia Nomor 54 Tahun 2007 tentang Pelaksanaan Pengangkatan Anak}

Peraturan Pemerintah (PP) RI Nomor 54 Tahun 2007 mengatur tentang pelaksanaan pengangkatan anak di Indonesia, peraturan pemerintah ini dibuat untuk melaksanakan ketentuan pengangkatan anak sebagaimana diatur dalam Undang-Undang Nomor 23 Tahun 2002 tentang Perlindungan Anak. Untuk itu perlu menetapkan peraturan pemerintah tentang pelaksanaan pengangkatan anak yang merupakan bagian dari aspek perlindungan anak.

Peraturan Pemerintah Nomor 54 Tahun 2007 Tentang Pengangkatan Anak memuat pengertian anak angkat dan pengangkatan anak, yaitu pasal 1 ayat 1 dan 2 yang berbunyi:

${ }^{24}$ Undang Undang Nomor 24 Tahun 2013 Tentang Perubahan Atas Undang-Undang Nomor 23 Tahun 2006 Tentang Administrasi Kependudukan. LN, RI Nomor 232 Tahun 2013.

${ }^{25}$ Undang Undang Nomor 24 Tahun 2013 Tentang Perubahan Atas Undang-Undang Nomor 23 Tahun 2006 Tentang Administrasi Kependudukan. LN, RI Nomor 232 Tahun 2013. 
ADHKI: Journal of Islamic Family Law

(1) Anak angkat adalah anak yang haknya dialihkan dari lingkungan kekuasaan keluarga orang tua, wali yang sah, atau orang lain yang bertanggung jawab atas perawatan, pendidikan, dan membesarkan anak tersebut, ke dalam lingkungan keluarga orang tua angkatnya berdasarkan keputusan atau penetapan pengadilan.

(2) Pengangkatan anak adalah suatu perbuatan hukum yang mengalihkan seorang anak dari lingkungan kekuasaan orang tua, wali yang sah, atau orang lain yang bertanggung jawab atas perawatan, pendidikan dan membesarkan anak tersebut, ke dalam lingkungan keluarga orang tua angkat. ${ }^{26}$

Menurut pasal di atas anak angkat adalah anak yang dialihkan dari lingkungan keluarga orang tua, wali sahnya ataupun orang lain yang bertanggung terhadap pengasuhan dan pendidikan anak ke dalam lingkungan keluarga orang tua angkat untuk mendapatkan hal yang sama yaitu pengasuhan, perawatan dan pendidikan. Dengan demikian pengangkatan anak tidak lain adalah peralihan tanggungjawab yang sebelumnya berada di bawah tanggungan orang tua dan/atau walinya menjadi tanggungan orang tua angkat. Pengangkatan anak merupakan peristiwa hukum yang dilakukan oleh seseorang, sehingga melahirkan akibat hukum berupa sahnya anak sebagai anak angkatnya, berpindahnya hak asuh kepadanya dan berkewajiban menjalankan ketentuan hak asuh sebagaimana yang diatur oleh perundang-undangan.

Tujuan pengangkatan anak tidak lain adalah untuk kepentingan terbaik anak, sebagaimana ditegaskan pada pasal 2 yang berbunyi: Pengangkatan anak bertujuan untuk kepentingan terbaik bagi anak dalam rangka mewujudkan kesejahteraan anak dan perlindungan anak, yang dilaksanakan berdasarkan adat kebiasaan setempat dan ketentuan peraturan perundang-undangan. ${ }^{27}$

Pasal di atas memuat dua hal, yaitu: Pertama, bahwa tujuan pengangkatan anak tidak lain kecuali untuk mewujudkan kesejahteraan hidup anak angkat dengan memberikan pengasuhan, perawatan dan membiayai pendidikannya, sehingga anak angkat tumbuh sehat dan berprestasi. Kedua, pengangkatan anak dapat dilakukan dengan dua cara yaitu berdasarkan adat kebiasaan setempat dan berdasarkan aturan perundang-undangan.

Ketentuan lain untuk mengangkat anak, bahwa orang tua angkat harus seagama dengan anak angkat, sebagaimana ditegaskan pada pasal 3 ayat 1 dan 2 yang berbunyi:

(1) Calon orang tua angkat harus seagama dengan agama yang dianut oleh calon anak angkat.

\footnotetext{
26Peraturan Pemerintah Republik Indonesia Nomor 54 Tahun 2007 tentang Pelaksanaan Pengangkatan Anak, LN Nomor 123 Tahun 2007.

27 Peraturan Pemerintah Republik Indonesia Nomor 54 Tahun 2007 tentang Pelaksanaan Pengangkatan Anak, LN Nomor 123 Tahun 2007.
} 
(2) Dalam hal asal usul anak tidak diketahui, maka agama anak disesuaikan dengan agama mayoritas penduduk setempat. ${ }^{28}$

Agama juga menjadi objek perhatian dalam pengangkatan anak di Indonesia, karena masalah ini dianggap rentan, sehingga perlu diatur sedemikian rupa supaya tidak terjadi hal yang membahayakan terhadap agama anak angkat. Perbedaan agama antara orang tua angkat dan anak angkat dikhawatirkan akan terjadi pemaksaan agama dikemudian hari oleh orang tua angkat kepada anak angkat, ini tentu saja merupakan kecelakaan bagi anak angkat. Pengangkatan anak sejatinya untuk memberikan yang terbaik bagi anak secara dunia dan ukhrawi, justeru menjadi malapetaka karena telah tertukar akidah dari yang benar kepada yang sesat.

Pengangkatan anak juga tidak mengakibatkan putusnya hubungan darah antara anak angkat dengan orang tua kandungnya, sebagaimana ditegaskan pada Pasal 4 yang berbunyi: "Pengangkatan anak tidak memutuskan hubungan darah antara anak yang diangkat dengan orang tua kandungnya." 29

Masalah hubungan darah juga menjadi perhatian, pengangkatan anak tidak mengakibatkan hubungan darah antara anak angkat dengan orang tua kandungnya terputus. Ketentuan ini menunjukkan bahwa pengangkatan anak di Indonesia semakin menjurus kepada ketentuan hukum Islam, dari segi tidak memutuskan hubungan darah anak angkat dengan orang tua kandung. Namun hal ini hanya berlaku bagi warga muslim, sedangkan bagi warga non muslim pengangkatan anak tetap memutuskan hubungan nasab, dikarenakan mereka menggunakan aturan hukum pengangkatan anak yang berbeda. Warga keturunan Tionghoa menggunakan Staatsblad 1917 Nomor 129 sebagai acuan pengangkatan anak, yang menjadikan anak angkat sebagai anak sah orang tua angkat, sehingga hubungan dengan orang tua kandung terputus.

Bagi sebahagian masyarakat Bali yang menganut agama Budha, mereka menggunakan hukum adat untuk mengangkat anak. Sebagaimana diuraikan sebelumnya bahwa dalam adat Bali pengangkatan anak adalah peristiwa penyerahan anak oleh petua adat kepada orang tua angkat untuk menjadi anak sahnya, serta memutuskan hubungan darah antara anak dengan orang tua kandung. Hal serupa juga ditemukan dalam adat Batak di Sumatera Utara, pengangkatan anak menurut adat setempat juga memutuskan hubungan darah antara anak dengan orang tua kandungnya.

Dalam Peraturan Pemerintah Nomor 54 Tahun 2007, orang tua angkat diharuskan memberitahukan asal usul anak angkat serta orang tua kandungnya di saat anak dianggap telah siap menerima berita tersebut, sebagaimana ditegaskan pada pasal 6 ayat 1 dan 2 yang berbunyi:

(1) Orang tua angkat wajib memberitahukan kepada anak angkatnya mengenai asal-

\footnotetext{
${ }^{28}$ Peraturan Pemerintah Republik Indonesia Nomor 54 Tahun 2007 tentang Pelaksanaan Pengangkatan Anak, LN Nomor 123 Tahun 2007.

${ }^{29}$ Peraturan Pemerintah Republik Indonesia Nomor 54 Tahun 2007 tentang Pelaksanaan Pengangkatan Anak, LN Nomor 123 Tahun 2007.
} 
usulnya dan orang tua kandungnya.

(2) Pemberitahuan asal-usul dan orang tua kandungnya sebagaimana dimaksud pada ayat (1) dilakukan dengan memperhatikan kesiapan anak yang bersangkutan. ${ }^{30}$

Isi pasal ini sangat berkaitan dengan Pasal 4 di atas, bahwa orang tua angkat harus memberitahukan asal usul anak angkat dan orang tua kandungnya di saat telah memungkinkan anak angkat menerima berita tersebut. Ketentuan ini menunjukkan anak angkat dan orang tua kandung masih memiliki hubungan, anak angkat masih tetap anak orang tuanya sekalipun dirawat dan dibesarkan oleh orang lain.

Peraturan Pemerintah Republik Indonesia Nomor 54 Tahun 2007 tentang Pelaksanaan Pengangkatan Anak adalah manifestasi dari komitmen pemerintah untuk memberikan perlindungan terhadap anak melalui Undang-undang Nomor 23 Tahun 2002 tentang Perlindungan Anak, yang mengatur tentang pengangkatan anak. Namun mengingat banyaknya penyimpangan atas pelaksanaan pengangkatan anak yang dilakukan masyarakat, seperti melakukan pengangkatan anak di luar prosedur yang benar, pemalsuan data, perdagangan anak, bahkan telah terjadi jual beli organ tubuh. Untuk itu perlu pengaturan dibuat tentang pelaksanaan pengangkatan anak.

Pengangkatan anak diawasi oleh pemerintah dan masyarakat untuk melakukan pembinaan dan pengawasan, ini penting untuk mengantisipasi penyimpangan dan pelanggaran dalam proses pengangkatan anak. Dalam peraturan Pemerintah ini juga menguraikan siapa saja atau instansi yang layak diawasi, yaitu orang perseorangan, lembaga pengasuhan, rumah sakit bersalon, praktek-praktek kebidanan, dan panti sosial pengasuhan anak.

Peraturan Pemerintah ini merupakan pedoman bagi pelaksanaan pengangkatan anak yang mencakup ketentuan umum, jenis pengangkatan anak, syarat-syarat pengangkatan anak, tata cara pengangkatan anak, bimbingan dalam pelaksanaan pengangkatan anak, pengawasan dalam pelaksanaan pengangkatan anak dan pelaporan. Dengan adanya peraturan tersebut dimaksudkan agar pengangkatan anak dilakukan sesuai dengan aturan perundang-undangan, sehingga tercapailah tujuan dari pengangkatan anak itu sendiri.

\section{Peraturan Menteri Sosial RI Nomor 110/HUK/2009 tentang Persyaratan Pengangkatan Anak}

Secara umum Peraturan Menteri Sosial Nomor 110/HUK/2009 mengatur tentang persyaratan pengangkatan anak, baik menyangkut anak angkat, orang tua angkat, persyaratan dan berbagai hal lain yang berkaitan dengan pengangkatan anak. Menyangkut pengertian pengangkatan anak dalam aturan

30 Peraturan Pemerintah Republik Indonesia Nomor 54 Tahun 2007 tentang Pelaksanaan Pengangkatan Anak, LN Nomor 123 Tahun 2007. 
ini tercantum pada pasal 1 ayat 2 yang berbunyi: "Pengangkatan Anak adalah suatu perbuatan hukum yang mengalihkan seorang anak dari lingkungan kekuasaan orang tua, wali yang sah atau orang lain yang bertanggung jawab atas perawatan, pendidikan dan membesarkan anak tersebut ke dalam lingkungan keluarga orang tua angkat."

Pengertian di atas persis sama dengan pengertian pengangkatan anak yang terdapat pada pasal 1 ayat 2 Peraturan Pemerintah Nomor 54 Tahun 2007 Tentang Pengangkatan Anak, dan pengertian pengangkatan anak dalam Kompilasi Hukum Islam, bahwa pengangkatan anak adalah pengalihan hak asuh dari orang tua atau wali anak kepada orang tua angkat.

Dalam pasal 2 ayat 1 peraturan ini diatur tentang prinsip pengangkatan anak, yaitu:

a. Pengangkatan anak hanya dapat dilakukan untuk kepentingan terbaik bagi anak dan dilakukan berdasarkan adat kebiasaan setempat dan ketentuan peraturan perundangundangan yang berlaku

b. Pengangkatan anak tidak memutuskan hubungan darah antara anak yang diangkat dengan orang tua kandungnya.

c. Calon orang tua angkat harus seagama dengan agama yang dianut oleh calon anak angkat.

d. dalam hal asal usul anak tidak diketahui, maka agama anak disesuaikan dengan agama mayoritas penduduk tempat ditemukannya anak tersebut; dan

e. Pengangkatan anak Warga Negara Indonesia oleh Warga Negara Asing hanya dapat dilakukan sebagai upaya terakhir.

Prinsip pengangkatan anak di atas sesuai dengan isi peraturan pemerintah tentang pelaksanaan pengangkatan anak, yang menyangkut dengan tujuan pengangkatan anak, tidak memutuskan hubungan darah anak angkat dengan orang tua kandung, orang tua angkat seagama dengan dengan anak angkat dan ketentuan tentang pengangkatan anak warga negara Indonesia oleh warga negara asing.

Peraturan Menteri Sosial ini lebih menekankan kepada persyaratan pengangkatan anak yang meliputi persyaratan calon orang tua angkat, calon anak angkat dan persyaratan administratif yang harus dipenuhi, baik pengangkatan anak secara langsung (dalam asuhan orang tua kandung), maupun melalui lembaga pengasuhan anak. Persyaratan ini dimaksudkan untuk menjamin bahwa orang tua angkat layak untuk mengangkat anak jika dapat memenuhi semua persyaratan, demikian pula anak juga layak untuk diangkat dengan adanya syarat-syarat yang diperlukan.

\section{Kesimpulan}

Peraturan-peraturan tentang pengangkatan anak di Indonesia sebagaimana telah diuraikan di atas sudah relatif telah sempurna, tidak hanya mengatur tentang prosedur pengangkatan anak dan akibat hukum setelahnya, tetapi juga mengatur tentang tata cara pelaksanaan pengangkatan anak antar warga negara, baik sesama warga negara Indonesia maupun warga negara 
ADHKI: Journal of Islamic Family Law

Indonesia yang mengangkat anak dari warga negara asing, begitu juga sebaliknya. Peraturan ini dibuat untuk terwujudnya tertib administrasi dan kebutuhan pembinaan dan pengawasan pengangkatan anak supaya tidak terjadi hal-hal yang merugikan anak angkat itu sendiri.

Peraturan pengangkatan anak di Indonesia juga berjalan sesuai dengan ketentuan Islam, di mana kedudukan atau hubungan anak angkat dengan orang tua angkat bukan berupa hubungan nasab (darah), melainkan hubungan kekeluargaan semata. Pengangkatan anak di Indonesia berdasarkan peraturan yang ada lebih mengacu kepada upaya pengasuhan dan pembiayaan terhadap anak angkat oleh orang tua angkat. Prinsip seperti ini sangat sesuai dengan cita hukum Islam yang menganjurkan saling tolong menolong sesama anggota masyarakat.

Peraturan pengangkatan anak di Indonesia sudah cukup baik dan telah sesuai dengan perkembangan dan kebutuhan masyarakat sekarang ini, tinggal lagi pelaksanaan harus dilakukan sesuai dengan aturan yang ada. Tentunya membutuhkan pembinaan dan pengawasan dari pemerintah dan masyarakat supaya pelaksanaan pengangkatan anak berjalan sesuai dengan ketentuan perundang-undangan.

\section{Daftar Pustaka}

Afdhol, Pengangkatan Anak dan Aspek Hukumnya Dalam Hukum Adat, (Makalah dalam Seminar tentang "Pengaturan dan Akibat Hukum Pengangkatan Anak".)

Ahmad Kamil dan Fauzan, Hukum Perlindungan dan Pengangkatan Anak di Indonesia, (Jakarta: Raja Grafindo, 2008), hlm. 20.

Ali Affandi, Hukum Waris Keluarga Hukum Pembuktian Menurut Kitab Undang Undang Hukum Perdata (BW), (Jakarta: Bina Aksara, 1986), hlm. 149.

Amir Mertosedono, Tanya Jawab Pengangkatan Anak dan Masalahnya, (Semarang: Dahara Prize, 1987, hlm. 22.

Bewa Ragawino, Pengantar dan Asas-Asas Hukum Adat Indonesia, (Bandung: Fakultas Ilmu Sosial dan Ilmu Politik Unpad, tt), hlm. 12.

Bushar Muhammad, Pokok-Pokok Hukum Adat, (Jakarta: Pradya Paramita, 1981), hlm. 29.

Departemen Agama RI, Tanya Jawab Kompilasi Hukum Islam, (Direktorat Jenderal Pembinaan Kelembagaan Agama Islam, 1997/1998), hlm. 134.

http://www.idlo.int/bandaacehawareness.HTM, di akses tanggal 31 Agustus 2014.

J. Satrio, Hukum Keluarga Tentang Kedudukan Anak Dalam Undang-Undang, (Bandung: Citra Aditya Bakti, 2000), hlm. 190-193.

Musthofa Sy, Pengangkatan Anak Kewenangan Pengadilan Agama, Cet. 1, (Jakarta: Kencana Prenada Media Group, 2008), hlm. 20.

Musthofa Sy, Pengangkatan Anak Kewenangan Pengadilan Agama..., hlm. 24-25. 
Peraturan Pemerintah Republik Indonesia Nomor 54 Tahun 2007 tentang Pelaksanaan Pengangkatan Anak, LN Nomor 123 Tahun 2007.

Putusan Pengadilan Negeri Istimewa Jakarta, dalam Putusan Tanggal 29 Mei 1963, Nomor 907/1963

Soedaryo Soimin, Himpunan Dasar Hukum Pengangkatan Anak, (Jakarta: Sinar Grafika, 2004), hlm. 28.

Ter Haar, Asas-asas dan Susunan Hukum Adat, (Jakarta: Praditya Paramita), 1994, hlm. 182

Undang Undang Nomor 24 Tahun 2013 Tentang Perubahan Atas UndangUndang Nomor 23 Tahun 2006 Tentang Administrasi Kependudukan. LN, RI Nomor 232 Tahun 2013.

Undang Undang Nomor 24 Tahun 2013 Tentang Perubahan Atas UndangUndang Nomor 23 Tahun 2006 Tentang Administrasi Kependudukan. LN, RI Nomor 232 Tahun 2013.

Undang Undang Republik Indonesia Nomor 23 Tahun 2002, Tentang Perlindungan Anak, LN Nomor 109 Tahun 2002.

Undang Undang Republik Indonesia Nomor 4 Tahun 1979, Tentang Kesejahteraan Anak, LN Nomor 32 Tahun 1979.

Undang-undang Dasar 1945 Pasal 18 B ayat (2)

Undang-Undang Nomor 12 Tahun 2006, Tentang Kewarganegaraan Republik Indonesia, LN Nomor 63 Tahun 2006. 